\title{
The Effect of Different Irrigation Water Levels on Grain Yield, Yield Components and Some Quality Parameters of Silage Maize (Zea mays indentata Sturt.) in Marmara Region of Turkey
}

\author{
Abdullah KARASU ${ }^{1 *}$, Hayrettin KUȘCU ${ }^{1}$, Mehmet ÖZ ${ }^{1}$, Gamze BAYRAM ${ }^{2}$ \\ ${ }^{1}$ Uludag University, Mustafakemalpasa Vocational School, Department of Plant Production, 16500 Bursa, Turkey; \\ akarasu@uludag.edu.tr(*correspondingauthor);kuscu@uludag.edu.tr;momer@uludag.edu.tr \\ ${ }^{2}$ Uludag University, Faculty of Agriculture, Department of Field Crops, 16059 Bursa, Turkey; gbayram@uludag.edu.tr
}

\begin{abstract}
This research was conducted in Bursa, Marmara region, Turkey, in order to determine grain yield and some morphological traits which affect the silage maize response to different irrigation water amounts. The grains' percentage of crude oil and of crude protein were determined. Field experiments were planned following randomized complete block design with three replications and included six irrigation treatments. Irrigation treatments were created as water levels of pan evaporation $\left(\mathrm{E}_{\mathrm{pan}}\right)$ applied via drip irrigation $\left[1.25 \times \mathrm{E}_{\mathrm{pan}}\left(\mathrm{I}_{125}\right), 1.00 \times \mathrm{E}_{\mathrm{pan}}\left(\mathrm{I}_{100}\right), 0.75 \times \mathrm{E}_{\mathrm{pan}}\left(\mathrm{I}_{75}\right), 0.50 \times \mathrm{E}_{\mathrm{pan}}\left(\mathrm{I}_{50}\right), 0.25 \times \mathrm{E}_{\mathrm{pan}}\left(\mathrm{I}_{25}\right)\right.$ and $0 \times \mathrm{E}_{\mathrm{pan}}$ $\left(\mathrm{I}_{0}\right)$ ]. The highest value of grain yield was found to be $18,268 \mathrm{~kg} \mathrm{ha}^{-1}$ in the $\mathrm{I}_{125}$ treatment, which represents excessive water. A quadratic relationship between grain yield and irrigation water applied was obtained. Deficit irrigation decreased grain yield and yield components except the percentage of crude oil and crude protein of grain, but improved the efficient use of irrigation water. Relationships between the grain yield and each yield component were positively significant. The highest correlation coefficient in the research gave the relationship between grain yield and plant height $\left(\mathrm{r}=0.957^{* *}\right)$. The results revealed that 1.25 $\times \mathrm{E}_{\mathrm{pan}}$ and $1.00 \times \mathrm{E}_{\mathrm{pan}}$ treatments are preferable for higher yield. The results of this study also suggest that if water is limited, the application of $0.75 \times \mathrm{E}_{\mathrm{pan}}$ can be recommended as optimal treatment, because the best compromise among yield, yield components, quality and irrigation water use efficiency for maize was achieved with this application.
\end{abstract}

Keywords: crude oil, crude protein, irrigation water productivity, morphological properties, seed quality, water stress

\section{Introduction}

Maize is one of the most important plants worldwide, because of its high grain and forage yield. It has extensive adaptation characters and is intensely cultivated in Turkey. The total production of maize is not sufficient to meet the continuous increase of consumption. Although the surfaces cultivated with maize are increasing, the total production of the maize is not sufficient in Turkey. Because of this, the attempts to increase maize production are of great importance. To increase the maize production, there are needs for the adequate supply of irrigation water, N, P, K fertilizers, high yielding cultivars, agronomical practices like optimum plant density, timing of different treatments and interventions etc. affecting directly the growth and productivity.

Maize is very sensitive to water stress (Rhoads and Bennett, 1990; Pandey et al., 2000; Cakir, 2004; Kuscu and Demir, 2013). Payero et al. (2009) reported that water stress can effect growth, development and physiological processes of maize plants, which reduce biomass yield. Farré and Faci
(2009) noted that the maize needs for the highest water amount is during the flowering period. Because of this, one of the most important factors that can limit crop production is availability of water. If water stress can be avoided during silking and early ear development, high yield could be expected.

Irrigation water supplies are decreasing in Turkey, likewise many areas of the world, in recent years. Because of the climate change, predictions of increase in temperature and decrease in rainfall mean, water will become increasingly scarce. Many farmers in Turkey are currently facing some irrigation water problems because of shortage irrigation water supplies. This water shortage has motivated some researchers and farmers to find ways to produce maize with less irrigation water and changing from fully-irrigated to deficit irrigated cropping system.

Water is usually the most important natural factor limiting expansion and development of agriculture in Marmara region, a sub-humid climate of Turkey. The total precipitation does not meet the water requirements of maize crop. Bursa has approximately $126 \mathrm{~mm}$ precipitation from 
the May to September, the growing season of maize, this being not enough for high maize yields. On the other hand, for the high yields, the seasonal water requirements of maize vary from 500 to $1,000 \mathrm{~mm}$ depending on the climate and the total length of the growing period. Therefore, irrigation is necessary for optimal vegetative and reproductive development in the periods of insufficient precipitation during the growing season in the Marmara region. The furrow and sprinkler irrigation methods are usually used for irrigation of maize in Turkey and Marmara region, because of the traditional habits. However, the use of drip irrigation has increased rapidly in the Turkish maize cultivation. The major reasons for the conversion from furrow and sprinkler irrigation are the improved water application efficiency provided by drip irrigation (Kuscu et al., 2014). Additionally, the limited fresh water resources and the cost of irrigation water are the most important reasons that induced many farmers to decrease irrigation in the Marmara region. Farmers in the region and researchers are motivated to find ways to produce crops with less irrigation water, such as using more efficient irrigation systems and changing from fully irrigated to deficit irrigated cropping systems (Kuscu et al., 2010). Some farmers think that when the amount of irrigation water is increased, the yield increases too, and because of this, they make excessive irrigation within the expectation of higher yield. This excessive irrigation can be seen especially in field areas with cheap irrigation water. However, excessive irrigation can cause some social problems such as the increase in frequency of water distribution conflicts. Furthermore, excessive irrigation increases the cost of production and cause environmental and agronomical problems such as salinity, erosion and drainage.

There are large populations of cattle in Marmara region. In some years, farmers who cultivate the maize for silage as a main crop or second crop, when the prices of silage are comparatively lower and there is more production than the need of farmers, leave the remaining product for grain productions. Namely, the maize grown for silage is kept waiting to obtained maize grain. Under these circumstances what is the grain yield of maize is important, like for silage.

The main aim of this study was 1) to determine the effect of different irrigation water amounts applied via drip irrigation on grain yield, some yield components and the content of crude protein and crude oil of silage maize grown in a sub-humid climate of Turkey, 2) to define correlation coefficients among yield and yield-related components in maize, 3) to conclude which irrigation appropriate for silage maize where growing sub-humid region of Turkey.

\section{Materials and methods}

Field experiments were conducted at the experimental station of the Mustafakemalpasa Vocational School, Uludag University located in Bursa, Turkey ( $40^{\circ} 02^{\prime} \mathrm{N}, 28^{\circ} 23^{\prime} \mathrm{E}, 25 \mathrm{~m}$ above sea level) for two consecutive summer seasons. The climate in this part of the country is classified as sub-humid according to mean rainfall amount (from 600 to $700 \mathrm{~mm}$ of annual precipitation) (Jensen, 1980). Long term annual total precipitation was $680 \mathrm{~mm}$, the mean temperature was $14.0^{\circ} \mathrm{C}$ and the relative humidity was $68 \%$ (means for the vegetation season of maize, along May to September, are $126.3 \mathrm{~mm}$ precipitation, $21.1{ }^{\circ} \mathrm{C}$ and $62.6 \%$ relative humidity). In the vegetation seasons of the experiment, these values were $77.1 \mathrm{~mm}, 23.7^{\circ} \mathrm{C}$ and $55.4 \%$ in the first year and $122.8 \mathrm{~mm}, 22.0^{\circ} \mathrm{C}$ and $65.8 \%$ in the second year, respectively. The soil in the experimental field was clay loam with low organic matter content and slightly alkaline nature with $\mathrm{pH}$ 7.8.

Treatments were arranged in the field according to a completely randomized block design with three replications, in both seasons. The treatments consisted of six irrigation levels of pan evaporation $\left(\mathrm{E}_{\mathrm{pan}}\right)$ replenishment $\left[1.25 \times \mathrm{E}_{\mathrm{pan}}\left(\mathrm{I}_{125}\right), 1.00 \times \mathrm{E}_{\mathrm{pan}}\right.$ $\left(\mathrm{I}_{100}\right), 0.75 \times \mathrm{E}_{\mathrm{pan}}\left(\mathrm{I}_{75}\right), 0.50 \times \mathrm{E}_{\mathrm{pan}}\left(\mathrm{I}_{50}\right), 0.25 \times \mathrm{E}_{\mathrm{pan}}\left(\mathrm{I}_{25}\right)$, and $0 \times \mathrm{E}_{\mathrm{pan}}$ $\left(\mathrm{I}_{0}\right)$ ]. The United States Weather Bureau (USWB) Class A evaporation pan was used to measure daily evaporation. Irrigation management was based on the common practice in the area for maize, which consists of irrigation at 7-day intervals. The area of each plot was $13.0 \mathrm{~m}^{2}$ (long: $5.00 \mathrm{~m}$, wide: $2.60 \mathrm{~m}$ ). A buffer zone of $2 \mathrm{~m}$ was provided between the plots. The variety hybrid 'Ada$523^{\prime}$ was planted at a spacing of $0.10 \mathrm{~m} \times 0.65 \mathrm{~m}$. There were 200 plants in each plot (15. 4 plants per $\mathrm{m}^{2}$ ). In the first year of experiment, maize was planted on May 10 and harvested on October 16. In the second year, maize was planted on May 17 and harvested on October 22. Two - fold seeds were sown at every 10 $\mathrm{cm}$ and $5 \mathrm{~cm}$ depth and hand - thinned to target densities with the first hoeing. Weeding was performed with hand twice during the growing season. Maize plots were fertilized with $180 \mathrm{~kg} \mathrm{ha}^{-1} \mathrm{~N}$ and $120 \mathrm{kgha}^{-1} \mathrm{P}_{2} \mathrm{O}_{5}$ in both years, before planting. In the field, all crops were irrigated by drip irrigation.

The drip irrigation system was designed and installed to meet the objectives of the project. The irrigation water was pumped directly from the Mustafakemalpasa Aquifer to the drip system. One screen filter was installed on the mainline to minimize dripper blockage. Low density polyethylene pipes of $32 \mathrm{~mm}$ diameter were used for sub-main. The lateral lines were laid adjacent to each crop row. The thick-walled dripper lines had inline compensating emitter pressure and the discharge rate of the emitters was $3.0 \mathrm{~L} \mathrm{~h}^{-1}$ at an operating pressure of $100 \mathrm{kPa}$. The emitter spacing was chosen as $0.30 \mathrm{~m}$ based on the soil characteristics.

The amount of first irrigation water for all the plots was based on the moisture deficit that would be needed to bring the $0-90 \mathrm{~cm}$ layer of soil to field capacity and it was applied using the drip irrigation system (Cetin et al., 2002). It was given $20 \mathrm{~mm}$ and 24 $\mathrm{mm}$ water for germination in the two years respectively, before seedling. The seasonal water applied in treatments $\mathrm{I}_{125}, \mathrm{I}_{100}, \mathrm{I}_{75}, \mathrm{I}_{50}$, $\mathrm{I}_{25}$ and $\mathrm{I}_{0}$ were $1.047,842,636,431,226$ and $20 \mathrm{~mm}$ in the first season of the experiment, and 1.007, 810, 613, 417, 220 and 24 mm for treatments $I_{125}, I_{100}, I_{75}, I_{50}, I_{25}$ and $I_{0}$ respectively, in the second year of the experiment. The differences between the seasonal water applied were simply due to the number of irrigation events in each season.

For morphological measurements, ten plants were randomly selected from each plot and taken just before harvesting for grain. Plant height, ear length, the number of row per ear, number of grain per row, the number of grain per ear, the number of ear per plant, 1,000 grain weight, hectoliter weight, grain yield, crude protein content and crude oil content were analyzed. Composition of crude protein and crude oil of maize were determined using the standard methods, as described in Association of Official Analytical Chemists (AOAC, 1990). Seed samples of plots were grounded to pass through a sieve of $0.8 \mathrm{~mm}$ diameter. Ground seed samples were analyzed by Kjeldahl method to determine the total nitrogen. Crude protein content was calculated by multiplying total nitrogen value with a coefficient of 6.25. Crude oil percentage was determined by the Soxhlet extraction technique. Approximately $3 \mathrm{~g}$ of sample were extracted 
140

with di-ethyl ether for a period of $4 \mathrm{~h}$ in Soxhlet device.

Two rows of the each plot were harvested for grain yield when the humidity of grain was $18 \%$. 1995):

The irrigation water use efficiency was calculated (Howell et al.

$$
\begin{array}{ll}
\text { IWUE } & =\left(\mathrm{GY}_{\mathrm{t}}-\mathrm{GY}_{\mathrm{ni}}\right) /\left(\mathrm{IR}_{\mathrm{t}}-\mathrm{IR}_{\mathrm{ni}}\right) \\
\text { where: } & \\
\mathrm{IWUE} & =\text { of treatment } \mathrm{t}\left(\mathrm{kg} \mathrm{m}^{-3}\right) \\
\mathrm{GY}_{\mathrm{t}} & =\text { grain yield of treatment } \mathrm{t}\left(\mathrm{kg} \mathrm{m}^{-2}\right) \\
\mathrm{GY}_{\mathrm{ni}} & =\text { grain yield of a nonirrigated treatment }\left(\mathrm{I}_{0}, \mathrm{gm}^{-2}\right) \\
\mathrm{IR}_{\mathrm{t}} & =\text { applied irrigation water to treatment } \mathrm{t}(\mathrm{mm}) \\
\mathrm{IR}_{\mathrm{ni}} & =\text { applied irrigation water for germination }(\mathrm{mm})
\end{array}
$$

The data were subjected to analyses of variance using MINITAB software. LSD test was used to group the means per year, irrigation and their interactions when the F-test was significant. The correlation coefficient between grain yield and yield components was calculated using the MINITAB software.

\section{Results and discussions}

\section{Results of variance analysis}

The analysis of variance indicated that growing season significantly affected all characters except ear length, the number of row per ear, the number of ear per plant, crude protein and crude oil percentage (Tables 1 and 2).

Results indicated that the effect of irrigation water amount was significant at $99 \%$ probability level for plant height, ear length, the number of grain per row, the number of grain in the ear, 1,000 grain weight, hectoliter weight, grain yield, and that was significant at $95 \%$ probability level for the number of row per ear and the number of ear per plant in average data of two years. The irrigation levels did not have effect on the percentage of crude protein and crude oil at averaged over two growing seasons. Additionally, the effects of the growing season $\mathrm{x}$ irrigation interactions on grain yield, number of grain per ear and plant height were significant at the $5 \%$ and $1 \%$ levels (Table 1 and Fig. 1). This result indicated that irrigation levels responses were various according to the seasons. Values related to these parameters increased as the irrigation water levels increased. However, the values obtained from the same irrigation water levels at different growing seasons formed different statistical groups and this situation leaded to interaction.

\section{Yield components}

Yield components such as plant height, ear length, the number of row per ear, the number of grain per row, the number of grain per ear and the number of ear per plant of maize grown under different levels of irrigation are shown in Table 1 and quality parameters including 1,000 grain weight, hectoliter weight, crude protein and crude oil in Table 2 .

The effect of different irrigation water amounts was statistically significant at plant height of silage maize. Results of combined data indicated that all applied water treatments yielded plants having higher and similar heights than unirrigated plants (Table 1). In similar experiments (Bozkurt et al, 2006; Cakir, 2004; Istanbulluoglu et al., 2002; Otegui et al., 1995; Pandey et al., 2000), plant heights were reported to be higher with full irrigation $(100 \%$ ETc or Epan = 1) and slightly deficit irrigation throughout the crop growing season, which is in agreement with the results of the current study.
As shown in Table 1, data obtained from two years study showed that ear length was significantly affected by irrigation levels $(p<0.01)$. The higher ear length values were obtained from treatments $I_{125}$ and $I_{100}(20.6 \mathrm{~cm}$ in both irrigation levels), while the shortest ear length $(16.0 \mathrm{~cm})$ was obtained from treatment $\mathrm{I}_{0}$. Because the ear length affects the number of grain per ear, it is accepted as one of the most important yield components that affects the grain yield. Our findings showed that when the irrigation levels decreased, the ear length decreased too. This result is consistent with the results of Ertek and Kara (2013). They showed that ear length was affected by different irrigation water levels $(12.8-18.8 \mathrm{~cm})$ and reported that the ear length decreased with decreasing water application. Kuscu (2010) noted that full irrigation during total crop growing season increased the ear length, but deficit irrigation at different phenological stages decreased it. In a similar study, Istanbulluoglu et al. (2002) reported values varying between 16.4 and 20.5 for ear length in relation to irrigation water levels.

The number of rows per ear was statistically affected by different irrigation water amounts (Table 1). Results revealed that the higher number of row per ear was found in treatments of $\mathrm{I}_{125}, \mathrm{I}_{100}, \mathrm{I}_{75}, \mathrm{I}_{50}$ and $\mathrm{I}_{25}(15.3,15.3,15.1,14.8$,and 14.7 respectively), whereas the lowest was found in non-irrigated plants (14.2). Our results are similar with those of Sampathkumar at al. (2013). In a study carried out by Esmailian et al. (2011) under the ecological conditions of Iran, the number of row per ear varied between 12.4 and 14.1. This result was lower than ours because of different cultivar and ecological conditions. Similar findings are reported by Kuscu (2010), who stated that the lowest number of row per ear was obtained from non-irrigated plots.

Differences between irrigation treatments were significant for the number of grain per row (Table 1). The highest number of grain per row was obtained from treatments of $\mathrm{I}_{125}, \mathrm{I}_{100}$, and $\mathrm{I}_{75}$ (42.4, 41.0 and 41.1, respectively), while the lowest was obtained from treatment $\mathrm{I}_{0}$ (33.9). Results showed that the number of grain per row increased as irrigation water amount increased up to I 75 level. Our results were similar with those of Claassen and Shaw (1970), Frey (1982), Fischer and Palmer (1984) and Kuscu (2010), who reported that the water stress decreased the number of grain per row at silking stage. The values of number of grain per row obtained in this study are in agreement with those of other researches on maize (Carpici, 2009; Okay, 2006; Turgut et al., 2005).

Significant differences between irrigation treatments were found in terms of the number of grain per ear for combined data of two years. The highest numbers of grain per ear were obtained from $I_{125}$ and $I_{100}$ irrigation water amounts (555.0 and 549.3, respectively), whereas the lowest number of grain per ear was obtained from non-irrigated treatment (413.3). The number of grain per ear is related with the ear length, the number of row per ear and the number of grain per row. It was seen that the number of grain per ear increased like the number of grain per row, as the amount of irrigation water was increased. The ear length, the number of row per ear and the number of grain per row gave the highest values when there was no deficit irrigation $\left(\mathrm{I}_{125}\right.$ and $\mathrm{I}_{100}$ irrigation levels).

At the applications of deficit irrigation, the values considerably decreased (Table 1). Ertek and Kara (2013) also reported that deficit irrigation decreased the number of grain per ear, which was in agreement with our findings. 
Table 1. Effect of irrigation water amounts on some morphological traits of maize and the result of $\mathrm{F}$ testing and statistical grouping irrigation water amount

\begin{tabular}{|c|c|c|c|c|c|c|}
\hline Irrigation treatments & $\begin{array}{c}\text { Plant height } \\
(\mathrm{cm})\end{array}$ & $\begin{array}{c}\text { Ear length } \\
(\mathrm{cm})\end{array}$ & $\begin{array}{c}\text { The number of } \\
\text { row per ear }\end{array}$ & $\begin{array}{l}\text { The number of } \\
\text { grain per row }\end{array}$ & $\begin{array}{l}\text { The number of } \\
\text { grain per ear }\end{array}$ & $\begin{array}{c}\text { The number of } \\
\text { ear per plant }\end{array}$ \\
\hline $\mathrm{I}_{0}$ & $267.3 \mathrm{c}$ & $16.0 \mathrm{~d}$ & $14.2 \mathrm{~b}$ & $33.9 \mathrm{~d}$ & $413.3 \mathrm{e}$ & $0.65 \mathrm{~b}$ \\
\hline $\mathrm{I}_{25}$ & $302.1 \mathrm{~b}$ & $17.6 \mathrm{c}$ & $14.7 \mathrm{ab}$ & $37.4 \mathrm{c}$ & $481.3 \mathrm{~d}$ & $0.83 \mathrm{a}$ \\
\hline $\mathrm{I}_{50}$ & $310.0 \mathrm{ab}$ & $19.7 \mathrm{ab}$ & $14.8 \mathrm{ab}$ & $39.4 \mathrm{bc}$ & $504.8 c$ & $0.86 \mathrm{a}$ \\
\hline $\mathrm{I}_{75}$ & $316.6 \mathrm{ab}$ & $19.4 b$ & $15.1 \mathrm{ab}$ & $41.1 \mathrm{ab}$ & $530.0 \mathrm{~b}$ & $0.88 \mathrm{a}$ \\
\hline $\mathrm{I}_{100}$ & $317.7 \mathrm{ab}$ & $20.6 \mathrm{a}$ & $15.3 \mathrm{a}$ & $41.0 \mathrm{ab}$ & $549.3 \mathrm{a}$ & $0.88 \mathrm{a}$ \\
\hline $\mathrm{I}_{125}$ & $323.3 \mathrm{a}$ & $20.6 \mathrm{a}$ & $15.3 \mathrm{a}$ & $42.4 \mathrm{a}$ & $555.0 \mathrm{a}$ & $0.89 \mathrm{a}$ \\
\hline \multicolumn{7}{|l|}{ Analysis of variance } \\
\hline Growing season & ** & ns & ns & $* *$ & ** & ns \\
\hline Irrigation & ** & $* *$ & $*$ & $* *$ & $* *$ & $*$ \\
\hline Growing season $\times$ irrigation & * & ns & ns & ns & ** & ns \\
\hline
\end{tabular}

Note: Means followed by the same letter are not significantly different at the $\mathrm{p}=0.05$ level using LSD test;

${ }^{* * *}$, ns F- test significant at $\mathrm{p} \leq 0.05, \mathrm{p} \leq 0.01$, respectively, and not significant

Table 2. Effect of irrigation water amounts on some quality characters of maize and the result of $\mathrm{F}$ testing and statistical grouping irrigation water amount

\begin{tabular}{|c|c|c|c|c|}
\hline Treatments & 1,000 grain weight $(\mathrm{g})$ & Hectoliter weight $\left(\mathrm{kg} \mathrm{hl}^{-1}\right)$ & Crude protein (\%) & Crude oil (\%) \\
\hline $\mathrm{I}_{0}$ & $261.2 \mathrm{e}$ & $63.1 \mathrm{c}$ & 8.6 & 3.3 \\
\hline $\mathrm{I}_{25}$ & $270.7 \mathrm{~d}$ & $63.4 \mathrm{c}$ & 8.3 & 3.2 \\
\hline $\mathrm{I}_{50}$ & $280.5 \mathrm{c}$ & $66.4 \mathrm{~b}$ & 8.2 & 3.4 \\
\hline $\mathrm{I}_{75}$ & $287.3 \mathrm{~b}$ & $67.8 \mathrm{ab}$ & 8.2 & 3.6 \\
\hline $\mathrm{I}_{100}$ & $308.0 \mathrm{a}$ & $69.1 \mathrm{a}$ & 8.2 & 3.2 \\
\hline$I_{125}$ & $309.3 \mathrm{a}$ & $69.2 \mathrm{a}$ & 7.8 & 3.0 \\
\hline Growing season & $* *$ & $* *$ & ns & ns \\
\hline Irrigation & $* *$ & $* *$ & ns & ns \\
\hline Growing season $\times$ irrigation & ns & ns & ns & ns \\
\hline
\end{tabular}

Note: Means followed by the same letter are not significantly different at the $\mathrm{p}=0.05$ level using LSD test;

$*^{* * *}$, ns F- test significant at $\mathrm{p} \leq 0.05, \mathrm{p} \leq 0.01$, respectively, and not significant

Table 3. Seasonal irrigation water applied, grain yield, irrigation water use efficiency (IWUE) and saved irrigation water for maize under different irrigation treatments in combined growing seasons

\begin{tabular}{|c|c|c|c|c|c|}
\hline Treatment & $\begin{array}{l}\text { Seasonal irrigation water } \\
\text { applied }(\mathrm{mm})\end{array}$ & Grain yield $\left(\mathrm{kg} \mathrm{ha}^{-1}\right)$ & IWUE $\left(\mathrm{kg} \mathrm{m}^{-3}\right)$ & $\begin{array}{c}\text { Grain yield losses } \\
(\%)\end{array}$ & $\begin{array}{c}\text { Irrigation water } \\
\text { saving }(\%)\end{array}$ \\
\hline $\mathrm{I}_{0}$ & $22^{x}$ & $7,123 \mathrm{f}$ & - & -59.9 & 97.4 \\
\hline $\mathrm{I}_{25}$ & 223 & $10,580 \mathrm{e}$ & 1.72 & -40.5 & 73.0 \\
\hline $\mathrm{I}_{50}$ & 424 & $13,383 \mathrm{~d}$ & 1.56 & -24.7 & 48.7 \\
\hline $\mathrm{I}_{75}$ & 625 & $15,702 \mathrm{c}$ & 1.42 & -11.7 & 24.4 \\
\hline $\mathrm{I}_{100}($ Control $)$ & 826 & $17,777 \mathrm{~b}$ & 1.32 & 0 & 0 \\
\hline $\mathrm{I}_{125}$ & 1027 & $18,268 \mathrm{a}$ & 1.11 & +2.76 & -24.4 \\
\hline
\end{tabular}

${ }^{\mathrm{x}}$ Irrigation water applied for germination in sowing time. The first irrigation water was applied for each treatment. Grain yields' means followed by the same letter are not significantly different at the $\mathrm{p}=0.05$ level using LSD test

Table 4. Correlation coefficients among yield and yield-related components in maize (averages of overall data)

\begin{tabular}{|c|c|c|c|c|c|c|c|c|}
\hline Parameters & 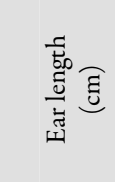 & 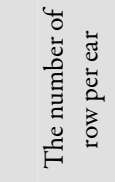 & 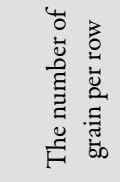 & 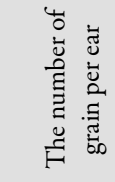 & 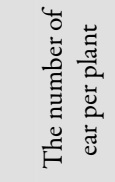 & 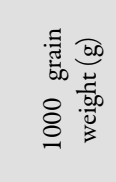 & 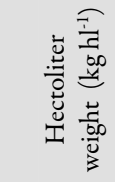 & 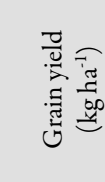 \\
\hline Plant height $(\mathrm{cm})$ & $0.830^{* *}$ & $0.772^{* *}$ & $0.578^{* *}$ & $0.883^{* *}$ & $0.875^{* *}$ & $0.890^{* *}$ & $0.761^{* *}$ & $0.957^{* *}$ \\
\hline Ear length $(\mathrm{cm})$ & & $0.592^{* *}$ & $0.598^{* *}$ & $0.643^{* *}$ & $0.754^{* *}$ & $0.717^{* *}$ & $0.513^{* *}$ & $0.844^{* *}$ \\
\hline The number of row per ear & & & $0.489^{* *}$ & $0.807^{* *}$ & $0.720^{* *}$ & $0.738^{* *}$ & $0.737^{* *}$ & $0.729^{* *}$ \\
\hline The number of grain per row & & & & $0.517^{* *}$ & $0.581^{* *}$ & $0.556^{* *}$ & $0.331^{* *}$ & $0.622^{* *}$ \\
\hline The number of grain per ear & & & & & $0.866^{* *}$ & $0.840^{* *}$ & $0.767^{* *}$ & $0.857^{* *}$ \\
\hline The number of ear per plant & & & & & & $0.805^{* *}$ & $0.647^{* *}$ & $0.894^{* *}$ \\
\hline 1000 grain weight $(\mathrm{g})$ & & & & & & & $0.713^{* *}$ & $0.938^{* *}$ \\
\hline Hectoliter weight $(\mathrm{kg})$ & & & & & & & & $0.675^{* *}$ \\
\hline
\end{tabular}

${ }^{* *}$ F-test significant at $\mathrm{p} \leq 0.01$ 
142

The effect of different irrigation water amounts was statistically important for the number of ear per plant of silage maize. The numbers of ear per plant varied between 0.89 and 0.65 number per plant. The higher number of ear per plant were obtained from $\mathrm{I}_{125}, \mathrm{I}_{100}, \mathrm{I}_{75}, \mathrm{I}_{50}$ and $\mathrm{I}_{25}$ treatments, which were statistically similar $(0.89,0.88,0.88,0.86$ and 0.83 , respectively), while the lowest value was determined at non-irrigated plots (0.65). The soil water stress affected the ear number per plant. Pandey et al. (2000) reported that water deficit decreased the ear number per unit area. Our results are similar with those of Cakir (2004) who reported the stress of water affected the ear number of per plant. Because of the higher plant density in our study (15.4 plant per $\mathrm{m}^{2}$ ) ear number per plant is less than those of some early researches (Carpici, 2009; Geren et al., 2003; Kusaksiz and Kaya, 2005; Turgut et al., 2005).

\section{Qualityparameters}

The effect of different irrigation water amount was statistically important for the 1,000 grain weight of silage maize for combined data of two years. As shown Table 2, the highest 1,000 grain weights were obtained from treatments of $I_{125}$ and $I_{100}$ (309.3 and $308.0 \mathrm{~g}$, respectively), while the lowest 1,000 grain weight was obtained from non-irrigated plots $(261.2 \mathrm{~g})$. As a result, 1,000 grain weight increased as the amount of irrigation water increased. Our results were in agreement with the results of Mansouri at al. (2010). They reported that when the amount of water decreased, both the 1,000 grain weight and grain yield were decreased. Similarly, Ogretir (1993) reported that the application of deficit irrigation on maize at the flowering period decreased the 1,000 grain. Cakir (2004) also stated that the irrigations during milk maturation period increased the 1,000 grain weight.

Hectoliter weight was statistically affected by different irrigation water amounts (Table 2). The highest hectoliter weights were obtained from treatments of $\mathrm{I}_{125} \mathrm{I}_{100}$ and $\mathrm{I}_{75}(69.2$, 69.1 and $67.8 \mathrm{~kg} \mathrm{~h}^{-1}$, respectively), while lower hectoliter weights were obtained from treatments of $I_{0}$ and $I_{25}\left(63.1\right.$ and $63.4 \mathrm{kghl}^{-1}$, respectively). Vartanli and Emeklier (2007) reported that hectoliter weights for different maize cultivars were between $65.43-73.53 \mathrm{~kg} \mathrm{~h}^{-1}$. In general, deficit irrigation levels adversely affected hectoliter weight (Kuscu, 2010).

The effect of different irrigation water amounts was not statistically important for crude protein content. As shown Table 2 , crude protein content ranged from 7.8 to $8.6 \%$. Similarly, Vartanli and Emeklier (2007) reported that crude protein contents of some maize cultivars were between 6.21 and $8.65 \%$. Conversely, Ertek and Kara (2013) who worked with the similar subjects on sugar maize reported that deficit irrigation levels affected the content of crude protein, which vary in their study between 10. 63 - 11.25\%. Esmailian et al. (2011), Farhad et al. (2013) and Aydinsakir et al. (2013) who worked on different irrigation water levels and different maize cultivars also reported that the grain protein contents were significantly influenced by different irrigation levels. The observed differences are possibly due to variations in experimental conditions and/or cultivar, soil and ecological differences.

Irrigation treatments had no statistically significant effect on crude oil content, for which the values ranged between 3.0-3.6\% (Table 2). In a similar study, Vartanli and Emeklier (2007) found that crude oil contents of some maize cultivars were between 2.04-6.90\%. However, in contrast to our findings, Farhad et al. (2013) reported that grain oil contents of maize hybrids were significantly affected with different irrigation water levels and the content of oil was differed among maize cultivars, varying between $1.95-4.55 \%$. In a similar study, Esmailian et al. (2011) also reported that the grain oil contents were significantly influenced with different irrigation levels. Cultivar and experimental conditions may be the cause of these differences.

\section{Grain yield and water-yield relationships}

Grain yield results according to irrigation treatments are shown Fig. 1. The grain yield was different between the two growing seasons at $99 \%$ probability level. Similarly, Mengü and Özgürel (2008) reported that the effects of years were important on grain yield. Additionally, the effect of the growing season $x$ irrigation interactions on grain yield was significant at $1 \%$ level (Fig. 1). This result indicated that irrigation levels responded variously according to the growing seasons. This may be attributed to the differences in climatic conditions among growing seasons. Irrigation water amounts applied in the first growing season were higher than the amounts in the second growing season due to the higher temperature and lower rainfall.

The effect of different irrigation water amounts was statistically important for grain yield per hectare for combined data of two years (Table 3). In general, there was a close relationship between irrigation and grain yield. The relationship between grain yield and irrigation water applied is shown in Fig. 2. The relationship was mainly quadratic due to excessive irrigation $\left(1.25 \mathrm{E}_{\mathrm{pan}}\right)$. The quadratic equation for the relationship between grain yield and seasonal irrigation water applied implies that a grain yield of approximately $6,669 \mathrm{~kg} \mathrm{ha}^{-1}$ can be achieved even without the application of irrigation water after germination. This is only possible if there is residual moisture in the soil to support such a yield (Igbadun et al., 2008). Quadratic relationships between grain yield and irrigation were also reported by Gencoglan and Yazar (1999), Kipkorir et al. (2002), Bozkurt et al. (2006) and Farré and Faci (2009). However, Payero et al. (2006) found that there was a linear relationship between grain yield and seasonal irrigation water amount. The differences among the relationships reported by different researchers are due to different experimental conditions, seasonal rainfall amounts and distribution (Howell et al., 1995).

In this study, the highest grain yield $\left(18,268 \mathrm{~kg} \mathrm{ha}^{-1}\right)$ was obtained in the treatment $\mathrm{I}_{125}$ due to satisfactory soil moisture during the growing period, while the lowest yield $\left(7,123 \mathrm{~kg} \mathrm{ha}^{-1}\right)$ was obtained from treatment $\mathrm{I}_{0}$. The second highest grain yield $\left(17,777 \mathrm{~kg} \mathrm{ha}^{-1}\right)$ was obtained in the $\mathrm{I}_{100}$ treatment. Furthermore, deficit irrigation applications decreased the grain yield. The results for the two years can be summarized by stating that a producer would have obtained the highest grain yield using full irrigation $\left(1.00 \times \mathrm{E}_{\mathrm{pan}}\right)$ or slightly excessive irrigation $(1.25 \times$ $\left.E_{\text {pan }}\right)$. This results are consistent with findings of Anac and Ul (1992), Yildirim at al. (1996), Stan and Naescu (1997), Pandey et al. (2000), Istanbulluoglu et al. (2002), Farre and Faci (2009), Ko and Piccinni (2009) and Mansouri et al. (2010), who showed that grain yield was affected by irrigation water amount.

As shown Table 3, irrigation water use efficiency (IWUE) values varied from 1.11 to $1.72 \mathrm{~kg} \mathrm{~m}^{-3}$, which are similar to reported values from 1.51 to $2.48 \mathrm{~kg} \mathrm{~m}^{-3}$ by Howell et al. (1995) and up to $1.62 \mathrm{~kg} \mathrm{~m}^{-3}$ reported by Kuscu and Demir (2013). Differences in the rainfall during growing seasons could be the cause of small differences in the results of IWUE values because the amount of rainfall affects the amount of irrigation water applied. In this study, irrigation water use efficiency increased 
with decreasing irrigation water applied. The highest IWUE was obtained from treatment $\mathrm{I}_{25}$. The relationship between IWUE and irrigation water applied is shown in Fig. 2.

In regions where water scarcity exists, irrigation managers should adopt the deficit irrigation approach to achieve sustainable crop production. In this study, compared to $\mathrm{I}_{100}$ (control) the least yield loss of $11.7 \%$ was seen in $\mathrm{I}_{75}$ treatment with $24.4 \%$ saving of irrigation water, and IWUE was also improved. Even though highest IWUE value was obtained from $\mathrm{I}_{25}$, grain yield was dramatically reduced $(-40.5 \%)$ (Table 3$)$.

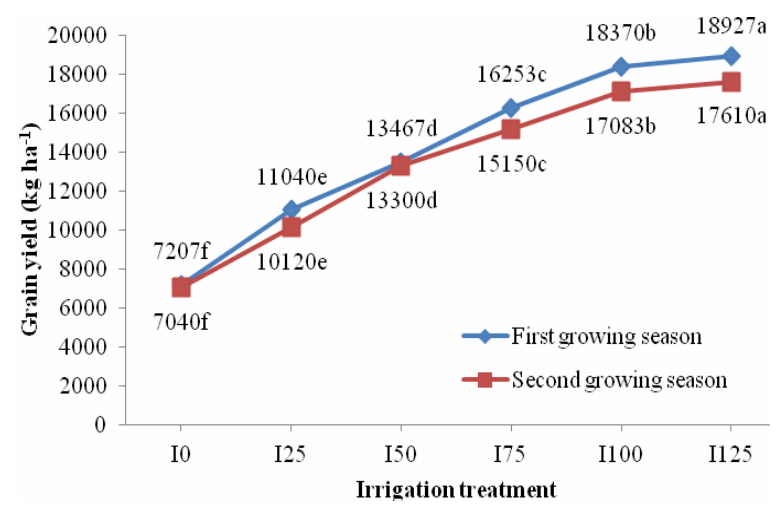

Fig. 1. Grain yield results according to irrigation treatments

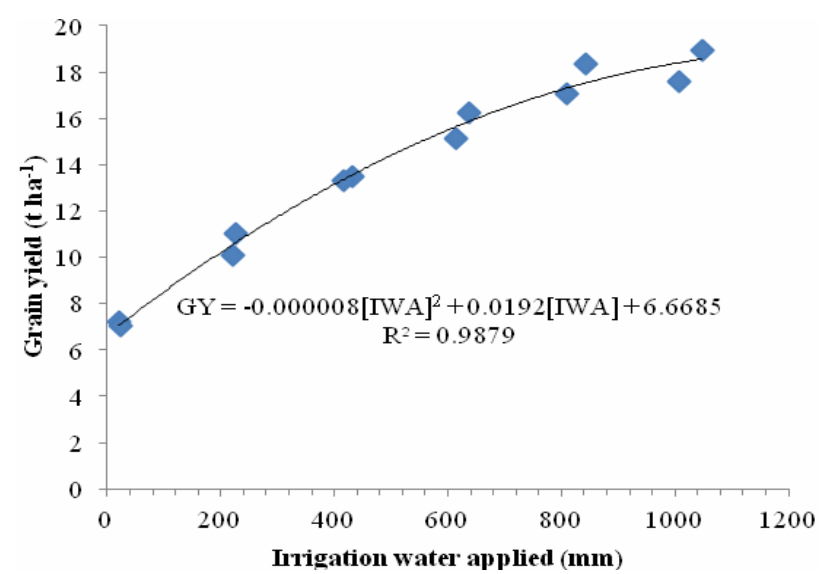

Fig. 2. Relationship between seasonal irrigation water applied (IWA) and grain yield (GY) (pooled data of the two growing seasons)

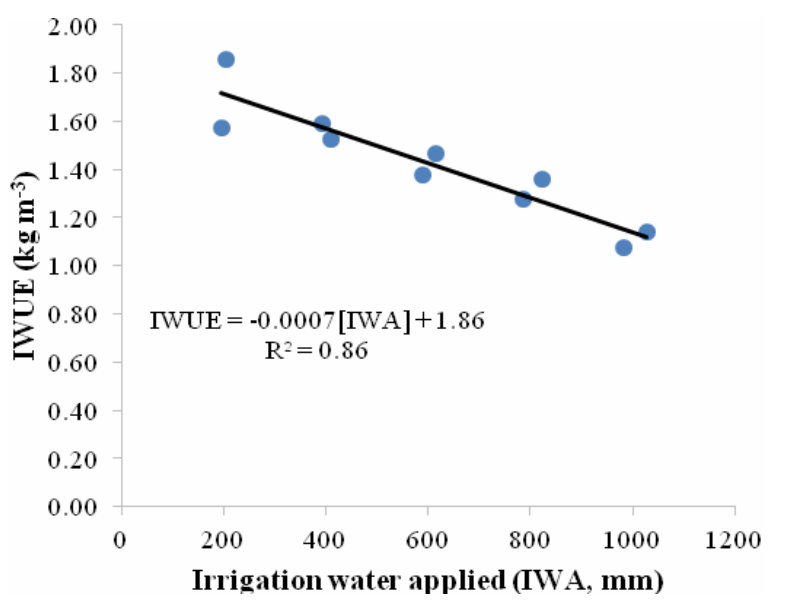

Fig. 3. Relationship between irrigation water applied and irrigation water use efficiency (IWUE)
Correlations between grain yield and yield components

The simple correlation coefficients averaged over all treatments are shown in Table 4. As can be seen, all correlation coefficients between yield and yield components were statistically significant $(\mathrm{p}<0.01)$. Positive and statistically significant relationships existed between the grain yield and all of yield components. The grain yield was positively and significantly correlated with plant height $\left(\mathrm{r}=0.957^{* *}\right), 1,000$ grain weight $(\mathrm{r}$ $\left.=0.938^{* *}\right)$, the number of ear per plant $\left(\mathrm{r}=0.894^{* *}\right)$, the number of grain per ear $\left(r=0.857^{* *}\right)$, ear length $\left(r=0.844^{* *}\right)$, the number of row per ear $\left(\mathrm{r}=0.729^{* *}\right)$, hectoliter weight $(\mathrm{r}=$ $\left.0.675^{* *}\right)$ and the number of grain per row $\left(\mathrm{r}=0.622^{* *}\right)$. In addition, all the reciprocal relationships among the variable all yield components were positively significant. For instance, the relationships between plant height and, 1,000 grain weight $(\mathrm{r}=$ $\left.0.890^{* *}\right)$, the number of grain per ear $\left(r=0.883^{* *}\right)$, the number of ear per plant $\left(r=0.875^{* *}\right)$, ear length $\left(r=0.830^{* *}\right)$, the number of row per ear $\left(r=0.772^{* *}\right)$, hectoliter weight $\left(r=0.761^{* *}\right)$, the number of grain per row $\left(r=0.578^{* *}\right)$ were positive and significant. Also, correlations between ear length and the number of ear per plant $\left(\mathrm{r}=0.754^{* *}\right), 1,000$ grain weight $(\mathrm{r}=$ $\left.0.717^{* *}\right)$, the number of grain per ear $\left(\mathrm{r}=0.643^{* *}\right)$, the number of grain per row $\left(r=0.598^{* *}\right)$, the number of row per ear $(r=$ $\left.0.592^{* *}\right)$, hectoliter weight $\left(\mathrm{r}=0.513^{* *}\right)$ were positively significant. The highest correlation coefficient in the research gave relationship between grain yield and plant height $\left(\mathrm{r}=+0.957^{*}\right)$ followed by correlations between grain yield and 1,000 grain weight $\left(\mathrm{r}=+0.938^{*}\right)$. Our findings on this subject are in agreement with those of Illker (2011), Hasyan et al. (2012) and Kumar et al. (2014) who reported that correlations were significant between yield and yield-related components of maize.

\section{Conclusions}

Irrigation levels significantly affected the maize grain yield, all morphological and quality parameters observed, except crude protein and crude oil. Deficit irrigation decreased the grain yield and yield components. The results of present research show that $1.25 \times \mathrm{E}_{\mathrm{pan}}$ and $1.00 \times \mathrm{E}_{\mathrm{pan}}$ irrigation applications at 7 day intervals during the total growing period can be considered as maximum grain yield in maize grown in ecological conditions of Marmara Region, Turkey. However, irrigation at $0.75 \times \mathrm{E}_{\mathrm{pan}}$ could be recommended where water resources are scarce such as that of present experiment. Because this DI regime achieved irrigation water savings up to $40 \%$ compared with $1.25 \times \mathrm{E}_{\mathrm{pan}}$. Because the grain yield of maize grown for silage was not lower than those grown for grain, this can be a solution for gaining profit if the prices of silage are comparatively lower or the production is too high compared with the demand at some moment.

\section{References}

Anac S, Ul MA (1992). Deficit irrigation studies on corn. Presented at the FAO/IAEA research co-ordination meeting on the use of nuclear and related techniques in assessment irrigation schedules of field crops to increase effective use of water. Irrigation Projects, 3 to 7 February 1992, Vienna, Austria.

AOAC (1990). Official methods of analysis. Association of Official Agricultural Chemists. Washington, DC. 
144

Aydinsakir K, Erdal S, Buyuktas D, Bastug R, Toker R (2013). The influence of regular deficit irrigation applications on water use, yield, and quality components of two corn (Zea mays L.) genotypes. Agricultural Water Management 128:65-71.

Bozkurt Y, Yazar A, Gencel B, Sezen MS (2006). Optimum lateral spacing for drip-irrigated corn in the Mediterranean Region of Turkey. Agricultural Water Management 85:113-120.

Cakir R (2004). Effect of water stress at different development stages on vegetative and reproductive growth of corn. Field Crops Research 89:1-16.

Carpici EB (2009). Evaluation of the effects of plant densities and nitrogen rates on stress physiology traits in silage corn (Zea mays L.) production. $\mathrm{PhD}$ thesis, Field Crops, Graduate School of Natural and Applied Sciences. Uludag University, Bursa, Turkey.

Cetin Ö, Yildirim O, Uygan D, Boyaci H (2002). Irrigation scheduling of drip-irrigated tomatoes using class a pan evaporation. Turkish Journal of Agriculture and Forestry 26:171-178.

Claassen MM, Shaw RH (1970). Water deficit effects on corn. I. Grain components. Agronomy Journal 62:652-655.

Ertek A, Kara B (2013).Yield and quality of sweet corn under deficit irrigation. Agricultural Water Management 129:138-144.

Esmailian Y, Ghanbari A, Babaeian M, Tavassoli A (2011). Influence of organic and inorganic fertilizers and wastewater irrigation on yield and quality traits of corn. American-Eurasian Journal of Agricultural \& Environmental Sciences 10(4):658666.

Farhad W, Cheema MA, Saleem MF, Radovich T, Abbas F, Hammad HM, Wahid MA (2013). Yield and quality response of maize hybrids to composted poultry manure at three irrigation levels. International Journal of Agriculture \& Biology 15:181-190.

Farré I, Faci JM (2009). Deficit irrigation in maize for reducing agricultural water use in a Mediterranean environment. Agricultural Water Management 96(3):383-394.

Fischer KK, Palmer FE (1984). Tropical maize. In: Goldsworthy PR, Fischer NM (Eds). The Physiology of Tropical Field Crops. Wiley, New York pp 213-248.

Frey NM (1982). Dry matter accumulation in kernels of maize. Crop Science 21:118-122.

Gencoglan C, Yazar A (1999). The effects of deficit irrigations on corn yield and water use efficiency. Turkish Journal of Agriculture and Forestry 23:233-242.

Geren H, Avcioğlu R, Kir B, Demiroğlu G, Yilmaz M, Cevheri AC (2003). Effect of different sowing dates on the yield and quality characteristics of some maize cultivars grown as second crop for silage. The Journal of Ege University Faculty of Agriculture 40(3):57-64.

Hasyan RM, Moualla YM, Ahmad AAS (2012). Potence ratio and path coefficient analysis for some quantitative traits of maize (Zea mays L.) hybrids developed in Syria. Jordan Journal of Agricultural Sciences 8(4):557-565.
Howell TA, Yazar A, Schneider AD, Dusek DA, Copeland KS (1995). Yield and water use efficiency of corn in response to lepa irrigation. Transactions of the ASAE 38(6):1737-1747.

Igbadun HE, Salim BA, Tarimo AKPR, Mahoo HF (2008). Effects of deficit irrigation scheduling on yields and soil water balance of irrigated maize. Irrigation Science 27(1):11-23.

Ilker E (2011). Correlation and path coefficient analyses in sweet corn. Turkish Journal of Field Crops 16(2):105-107.

Istanbulluoglu A, Kocaman I, Konukcu F (2002). Water useproduction relationship of maize under Tekirdag conditions in Turkey. Pakistan Journal of Biological Science 5(3):287-291.

Jensen ME (1980). Design and operation of farm irrigation systems. An ASAE Monography, Number 3 in a Series Published by American Society of Agricultural Engineers, 2950 Niles Road, Michigan 49085, USA.

Kipkorir EC, Raes D, Massawe B (2002). Seasonal water production functions and yield response factors for maize and onion in Perkerra, Kenya. Agricultural Water Management 56:229-240.

Ko J, Piccinni G (2009). Corn yield responses under crop evapotranspiration-based irrigation management. Agricultural Water Management 96:799-808.

Kumar GP, Prashanth Y, Reddy VN, Sudheer S, Rao VP (2014). Character association and path coefficient analysis in maize (Zea mays L.). International Journal of Applied \& Biology and Pharmaceutical Technology 5(1):257-260.

Kusaksız T, Kaya C (2005). An investigation on the herbage yield of different maize cultivars (Zea mays L.) grown under Manisa conditions. Turkey VI. Field Crops Congress, September 5-9, Antalya 2:1021-1026.

Kuscu H (2010). Effects of deficit irrigation on yield and yield components of maize grown under Bursa conditions. $\mathrm{PhD}$ thesis, Irrigation and Agricultural Structures, Graduate School of Natural and Applied Sciences, Uludag University, Bursa, Turkey.

Kuscu H, Karasu A, Öz M (2010). Effects of drip irrigation on corn yield in Bursa conditions. I. National Symposium on Irrigation and Agricultural Structures. Kahramanmaras, Turkey, May 2729, 1:156-167.

Kuscu H, Demir AO (2013). Yield and water use efficiency of maize under deficit irrigation regimes in a sub-humid climate. Philippine Agricultural Scientist 96(1):32-41.

Kuscu H, Karasu A, Öz M, Demir A, Turgut I (2013). Effect of irrigation amounts applied with drip irrigation on maize evapotranspiration, yield, water use efficiency, and net return in a sub-humid climate. Turkish Journal of Field Crops 18:13-19.

Kuscu H, Turhan A, Demir AO (2014). The response of processing tomato to deficit irrigation at various phenological stages in a sub-humid environment. Agricultural Water Management 133:92-103.

Mansouri-Far CSA, Sanavy MM, Saberali SF (2010). Maize yield response to deficit irrigation during low sensitive growth stages and nitrogen rate under semi-arid climatic conditions. Agricultural Water Management 97(1):12-22. 
Mengü GP, Özgürel M (2008). An evaluation water-yield relations in maize (Zea mays L.) in Turkey. Pakistan Journal of Biological Sciences 11(4):517-524.

Ogretir K (1993). The water-yield relationships of corn in Eskişehir conditions. $\mathrm{PhD}$ thesis, Irrigation and Agricultural Structures, Graduate School of Natural and Applied Sciences. Cukurova University, Adana.

Okay D (2006). Determination of corn plant water-yield relationships with CERES-maize model in Bursa conditions. $\mathrm{PhD}$ thesis, Irrigation and Agricultural Structures, Graduate School of Natural and Applied Sciences. Uludag University, Bursa, Turkey.

Otegui ME, Andrade FH, Suero EE (1995). Growth, water use and kernel abortion of maize subjected to drought at silking. Field Crops Research 40(2):87-94.

Pandey RK, Maranville JW, Admou A (2000). Deficit irrigation and nitrogen effects on maize in Sahelian environment. II. Shoot growth. Agricultural Water Management 46(1):1-13.

Payero JO, Steven M, Irmak S, Tarkalson DD (2006). Yield response of corn to deficit irrigation in a semiarid climate. Agric Water Manage 84:895-908.

Payero JO, Tarkalson DD, Irmak S, Davison D, Petersen JL (2009). Effect of timing of a deficit-irrigation allocation on corn evapotranspiration, yield, water use efficiency and dry mass. Agricultural Water Management 96:1387-1397.
Rhoads FM, Bennett JM (1990). Corn. In: Stewart BA, Nielsen DR (Eds). Irrigation of agricultural crops. Madison, WI, ASA, CSSA, and SSSA, Agronomy Monograph 30:569-596.

Sampathkumar T, Pandian BJ, Rangaswamy MV, Manickasundaram P, Jeyakumar P (2013). Influence of deficit irrigation on growth, yield and yield parameters of cotton-maize cropping sequence. Agricultural Water Management 130:90102.

Stan I, Naescu V (1997). Maize response to water deficit. Romanian Agriculture Research 7-8:77-90.

Turgut I, Duman A, Bilgili U, Açikgoz E (2005). Alternate row spacing and plant density effects on forage and dry matter yield of corn hybrids (Zea mays L.) Journal of Agronomy and Crop Science 191:146-151.

Vartanlı S, Emeklier HY (2007). Determination of the yield and quality characteristics of hybrid maize varieties under Ankara conditions. Journal of Agricultural Sciences 13(3):195-202.

Yildirim O, Kodal S, Selenay F, Yildirim YE, Oztürk A (1996). Corn grain yield response to adequate and deficit irrigation. Turkish Journal of Agriculture and Forestry 20(4):283-288. 